\title{
Genetic polymorphisms of the IGF-II gene intron 8 coding region and its association with growth and carcass traits in yak
}

\author{
Y.F. Zeng ${ }^{1,2}$, X.Z. Ding ${ }^{2}$, S.R. Cheng ${ }^{3}$ and S.J. Yu ${ }^{1}$ \\ ${ }^{1}$ College of Veterinary Medicine, Gansu Agricultural University, \\ Lanzhou, China \\ ${ }^{2}$ Institute of Lanzhou Animal Science and Veterinary Pharmaceutics, \\ Chinese Academy of Agricultural Sciences, Lanzhou, China \\ ${ }^{3}$ College of Animal Science and Technology, \\ Gansu Agricultural University, Lanzhou, China \\ Corresponding author: S.J. Yu \\ E-mail: sjyu@163.com
}

Genet. Mol. Res. 12 (4): 6602-6610 (2013)

Received January 8, 2013

Accepted October 10, 2013

Published December 11, 2013

DOI http://dx.doi.org/10.4238/2013.December.11.11

\begin{abstract}
Insulin-like growth factor II (IGF-II) plays a key role in mammalian growth and is involved in stimulating fetal cell division, differentiation, and metabolic regulation. IGF-II is considered a candidate gene for genetic markers of growth and carcass traits. Therefore, in this study, the associations of single nucleotide polymorphisms (SNPs) in the IGF-II gene region with growth and carcass characteristics in five yak breeds were investigated. Two SNPs, $\mathrm{G}_{330} \mathrm{C}$ and $\mathrm{A}_{358} \mathrm{G}$, were identified by sequencing intron 8 of the IGF-II gene in homozygotes. Two alleles, $\mathrm{A}$ and $\mathrm{B}$, and three genotypes, AA, $\mathrm{AB}$, and $\mathrm{BB}$, were identified by polymerase chain reaction. Genotypic frequencies of IGF-II allele B were 0.8623, 0.8936, 0.8535, 0.8676, and 0.8300 for Datong yak, Gannan yak, Tianzhu white yak, Qinghai Plateau yak, and Xinjiang yak, respectively. Allele and the genotype of IGF-II were strongly associated with growth and carcass traits. Least
\end{abstract}


square analysis revealed a significant effect $(\mathrm{P}<0.01)$ of genotypes AA and $\mathrm{AB}$ compared with genotype $\mathrm{BB}$ on live-weight (at 12, 13-24, and 25-36 months of age), average daily weight gain $(\mathrm{P}<0.01)$ and carcass weight $(\mathrm{P}<0.05)$. Animals with genotype $\mathrm{AB}$ had a higher mean rib eye area, and a lower mean yield grade. The results indicated that the IGFII gene acts by a primarily additive biological mechanism by adding weight independently of skeletal growth.

Key words: Yak; Insulin-like growth factor II; Polymorphism; Growth traits

\section{INTRODUCTION}

The activities of growth hormones have long been known to be mediated through secondary agents, which led to the discovery of insulin-like growth factors (IGFs) (Salmon Jr. and Daughaday, 1957; O'Dell and Day, 1998). IGFs are members of a protein family that is involved in satellite cell differentiation and proliferation (Haugk et al., 1995; Florini et al., 1996). One member of this family, IGF-II, plays a crucial role in muscle growth and differentiation. Therefore, the IGF-II gene is considered to be a candidate molecular marker for selection of favorable meat production traits in farm animals (Zwierzchowski et al., 2010), and has been found to increase in response to degeneration and regeneration, thereby influencing satellite cell activation (Levinovitz et al., 1992; Florini, et al., 1996; Marsh et al., 1997; Bamman et al., 2001; Adams, 2002). Research in pigs has revealed quantitative trait loci (QTL) affecting growth, muscle mass, or fat deposition that map to IGF-I and IGF-II loci (Casas-Carrillo et al., 1997; Nezer et al., 1999; Van Laere et al., 2003).

Only a few single nucleotide polymorphisms (SNPs) have been found in the bovine IGF-II gene (Zwierzchowski et al., 2010). Curchoe et al. (2005) identified an SNP in exon 3 and an SNP after the stop codon of exon 10, and an indel in IGF-II of Bos taurus was reported by Flisikowski et al. (2006). A C/T transition (RFLP-BsrI) at position 292 was first reported by Goodall and Schmutz (2003). This polymorphism was later associated with rib-eye area (REA) and carcass fat percentage in beef cattle (Goodall and Schmutz, 2007). In another study, a g.292C $>$ T polymorphism was found to strongly affect the longissimus dorsi muscle area, back fat, average daily weight gain (ADG), and feed conversion ratio (Sherman et al., 2008). Zhao et al. (2002) found a T/G transversion (RFLP-AciI) in exon 9 of the IGF-II gene in Angus cattle, in which animals with the GG genotype tended to have higher body weights and ADG. Moreover, a correlation between IGF-II and slaughter traits was also found in beef cattle. Preferential paternal expression of the IGF-II gene was first reported by Dindot et al. (2004). In addition, Curchoe et al. (2005) showed a promoter-specific loss of imprinting of the IGF-II gene in cattle after birth.

Extensive yak crossbreeding practices have been adopted in China in recent years. Yak breeding has resulted in substantial increases in milk and meat production for Tibetanherders. As body development and productivity are positively associated, an animal's early growth is very important for high productivity in later life. Identification of suitable markers is crucial for crossbred populations, particularly because the Indicine and Taurine yak breeds differ substantially in economically important traits, and there is vast genetic variability in the 
crossbred population. The present investigation was conducted to investigate DNA polymorphisms of the yak IGF-II gene, and to explore its possible associations with growth traits. The results of this study will be beneficial for cattle breeding and genetics.

\section{MATERIAL AND METHODS}

\section{Animals}

Five yak breeds were included in the present study. The Tianzhu white yak (WY, N = 111 ) is found in the Tianzhu autonomous country of Gansu Province, which is located at the eastern end of the Qilian mountains and at the northern edge of the Qinghai-Tibetan Plateau $\left(102^{\circ} 02^{\prime}-103^{\circ} 29^{\prime} \mathrm{E} ; 36^{\circ} 29^{\prime}-37^{\circ} 41^{\prime} \mathrm{N}\right)$. The Qinghai Plateau yak (PY, N = 70) is found in the cold highland pasture of the southern and northern ends of the Qinghai Province, where it overlaps with the wild yak distribution. The Xinjiang yak $(X Y, N=50)$ is found mainly in Hejing (83$\left.93^{\circ} 56^{\prime} \mathrm{E} ; 36^{\circ} 11^{\prime}-43^{\circ} 20^{\prime} \mathrm{N}\right)$, which is located in the Xinjiang Uyghur autonomous region. The Gannan yak (GY, N = 95) is raised in the Gannan Tibetan autonomous prefecture of Gansu $\left(100^{\circ} 46^{\prime}-104^{\circ} 45^{\prime} \mathrm{E} ; 33^{\circ} 06^{\prime}-35^{\circ} 43^{\prime} \mathrm{N}\right)$. The world's first yak breed, Datong yak (DY, N=72), mainly distributed on the Datong Yak Breeding Farm of Qinghai Province, China. (Figure 1).

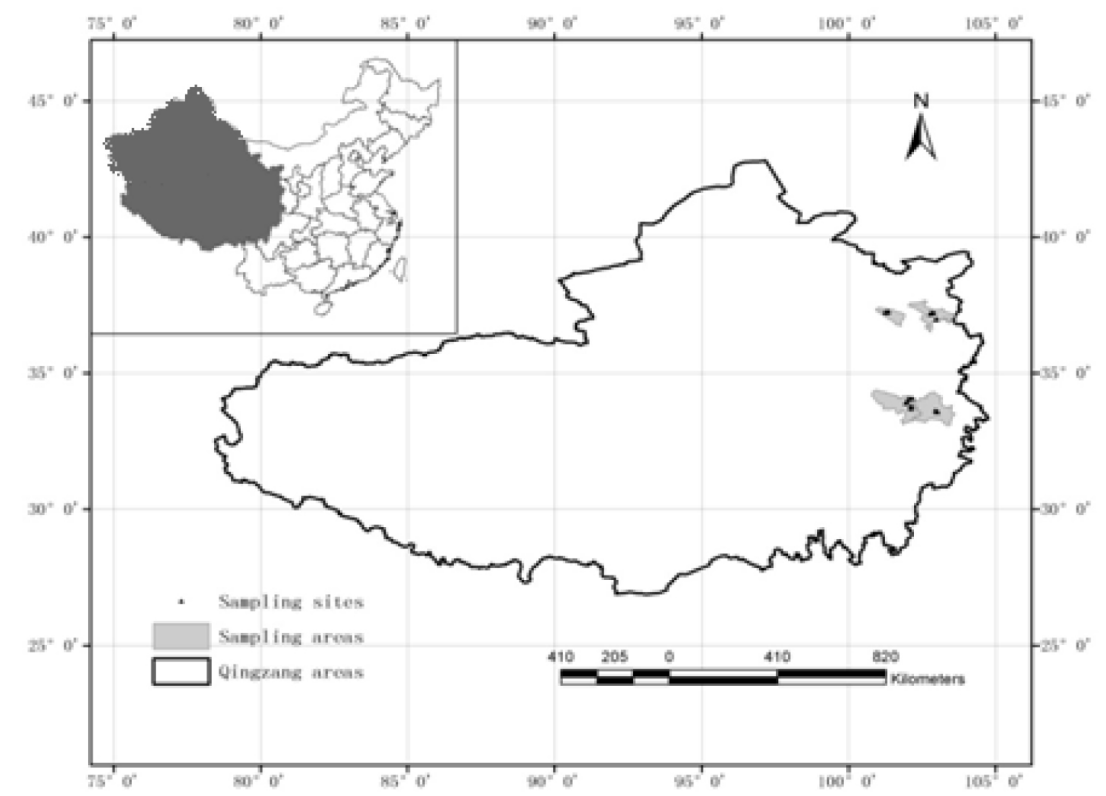

Figure 1. Geographic locations of the five yak breeds (Tianzhu white yak, WY; Qinghai Plateau yak, PY; Xinjiang yak, XY; Gannan yak, GY; Datong yak, DY).

Ten-milliliter blood samples were collected from the vena jugularis, mixed with $2 \mathrm{~mL}$ acid citrate dextrose, immediately frozen in liquid nitrogen, and stored at $-80^{\circ} \mathrm{C}$ until genomic DNA extraction. Total DNA was extracted according to the standard phenol-chloroform extraction protocol (Joseph and David, 2002). 
The growth traits (live-weight (LW) and ADG) and carcass traits [carcass weight, viscera fat weight, loin-eye area (LEA)] of $111 \mathrm{WY}$ at different growth periods $(1,2$, and 3 months old) were measured and recorded according to methods described in Ding et al. (2012).

\section{Primer design and polymerase chain reaction (PCR) amplification}

Genomic DNA (50 ng) was subjected to PCR. The partial fragments of IGF-II were amplified by PCR using three sets of degenerated primers, which were designed based on publicly available cattle sequences (GenBank accession No. NW-001494548). The forward and reverse primers were 5'-AGGTGGCTGGGCTTAGGGT-3' and 5'-GCGAGTCATGTGGCTGGAA-3'.

The PCR was carried out in a $20-\mu \mathrm{L}$ reaction volume containing $1.5 \mathrm{mM} \mathrm{MgCl}_{2}, 0.2 \mathrm{mM}$ of each dNTP, $0.5 \mathrm{U}$ Taq DNA polymerase (TaKaRa, China), and $0.4 \mu \mathrm{M}$ of each primer. Ten cycles of amplification were carried out for each PCR. Each cycle consisted of an initial step at $94^{\circ} \mathrm{C}$ for $5 \mathrm{~min}$, a denaturation step at $95^{\circ} \mathrm{C}$ for $30 \mathrm{~s}$, annealing temperatures for $40 \mathrm{~s}$, and extension at $72^{\circ} \mathrm{C}$ for $40 \mathrm{~s}$. The final extension step was followed by a 10 -min extension reaction at $72^{\circ} \mathrm{C}$.

\section{PCR-single-strand conformation polymorphism (SSCP) analysis}

The PCR products were analyzed by the SSCP technique and were sequenced on an ABI 377 sequencer in both directions (Applied Biosystems, USA). Aliquots $(2 \mu \mathrm{L})$ of PCR products were mixed with $6 \mu \mathrm{L}$ denaturing solution, heated for $10 \mathrm{~min}$ at $98^{\circ} \mathrm{C}$, and then chilled on ice. The denatured DNA was subjected to polyacrylamide gel electrophoresis with $1 \%$ Tris-borate-EDTA (TBE) buffer ( $89 \mathrm{mM}$ Tris-borate, $2 \mathrm{mM}$ EDTA, $\mathrm{pH}$ 8.3) under constant voltage $(180 \mathrm{~V})$ for $2.5 \mathrm{~h}$ at $4^{\circ} \mathrm{C}$. The gel was stained with silver nitrate and was visualized with $2 \% \mathrm{NaOH}$ solution containing $0.1 \%$ formaldehyde.

\section{Statistical analysis}

Genotypic and allelic frequencies were directly calculated. All sequences determined in this study were edited using the DNAStar 5.0 software package. The associations between SNP marker genotypes and growth traits in yaks (WY were analyzed using the SPSS 13.0 software according to the following linear model:

$$
\mathrm{Y}_{i j k l m n}=\mu+\mathrm{B}_{i}+\mathrm{F}_{j}+\mathrm{M}_{k}+\mathrm{G}_{l}+\mathrm{S}_{m}+\mathrm{e}_{i j k l m n}
$$

where $Y_{i j k l m n}$ is the observed value; $\mu$ is the overall mean for each trait; $B_{i}$ is the fixed effect of the $i$ th breed; $F_{j}$ is the fixed effect of the $j$ th farm; $M_{k}$ is the fixed effect of the $k$ th month of surveying; $G_{l}$ is the fixed effect of the $l$ th single SNP marker genotype; $S_{m}$ is the fixed effect of sex; $e_{i j k l m n}$ is the random error.

\section{RESULTS}

\section{PCR-SSCP analysis of the IGF-II gene}

Genetic polymorphisms of the sampled population were first detected by PCR-SSCP 
at the intron 8 locus of yak steers, and three genotypes were found, designated as $\mathrm{AA}, \mathrm{AB}$, and $\mathrm{BB}$ (Figure 2). Sequencing of the homozygote revealed a $\mathrm{G} \rightarrow \mathrm{C}$ transition at $330 \mathrm{bp}$ and an $\mathrm{A} \rightarrow \mathrm{G}$ transition at $358 \mathrm{bp}$ in the wild type (Figure 3).

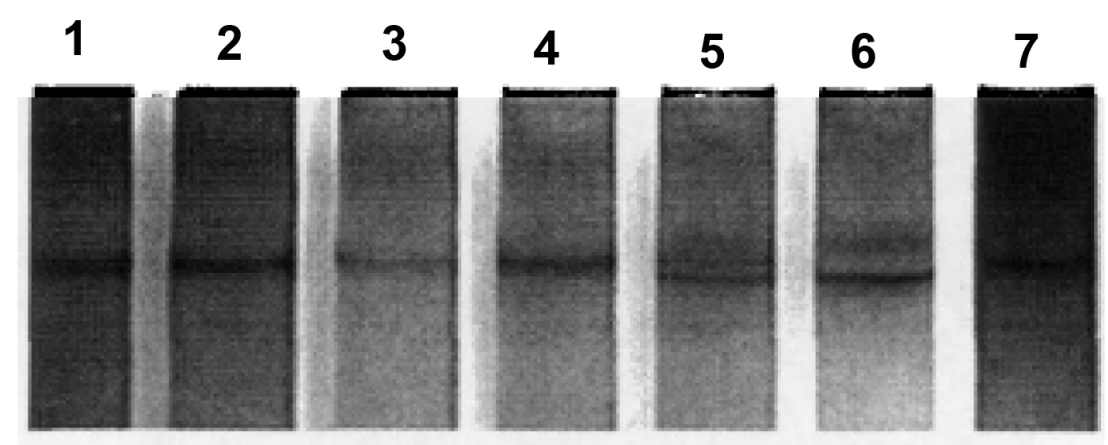

Figure 2. Electrophoresis patterns of PCR-SSCP for the IGF-II gene intron 8 in yak. Lanes 1, 2, 3, 4, $7=$ BB genotype; lane $5=\mathrm{AB}$ genotype; lane $6=\mathrm{AA}$ genotype.
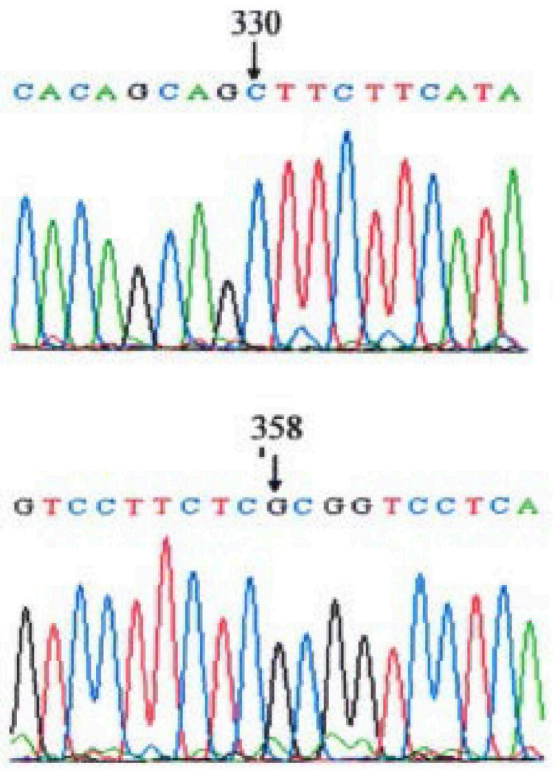
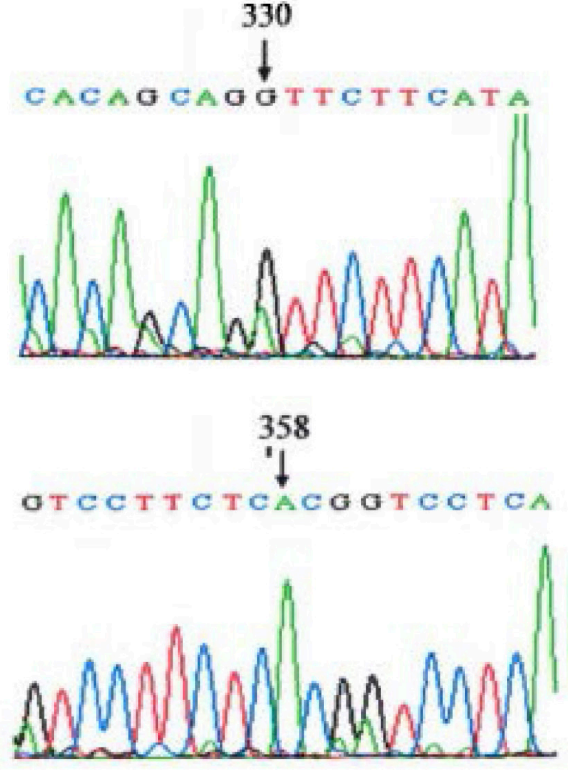

Figure 3. Partial sequencing maps of intron 8 of the IGF-II gene in yak.

The frequencies of the intron 8 IGF-II alleles were investigated for Hardy-Weinberg equilibrium with the $\chi^{2}$ test in all populations from the different locations sampled in the present study. The results showed that the frequencies of IGF-II allele B were 0.8623, 0.8936, $0.8535,0.8676$, and 0.8300 in DY, GY, WY, PY, and XY, respectively. All breeds except for $\mathrm{XY}$ were in Hardy-Weinberg disequilibrium (Table 1). According to the polymorphism information content (PIC) classification (low polymorphism $=\mathrm{PIC}<0.25$, intermediate poly- 
morphism $=0.25<$ PIC $<0.5$, and high polymorphism $=$ PIC $>0.5)$, all analyzed samples possessed low genetic diversity (PIC value $<0.25$ ) (Table 1).

\begin{tabular}{|c|c|c|c|c|c|c|c|c|c|c|c|c|c|c|}
\hline \multirow[t]{2}{*}{ Breeds } & \multicolumn{3}{|c|}{ No. of each genotype } & \multicolumn{3}{|c|}{ Genotypic frequency } & \multicolumn{2}{|c|}{ Allelic frequency } & \multirow[t]{2}{*}{ Equilibrium $\chi^{2}$ test } & \multirow[t]{2}{*}{ HWE } & \multirow[t]{2}{*}{$H_{\mathrm{E}}$} & \multirow[t]{2}{*}{$H_{\mathrm{O}}$} & \multirow[t]{2}{*}{$N_{\mathrm{E}}$} & \multirow[t]{2}{*}{ PIC } \\
\hline & AA & $\mathrm{AB}$ & BB & $\mathrm{AA}$ & $\mathrm{AB}$ & BB & A & B & & & & & & \\
\hline DY & 1 & 17 & 51 & 0.015 & 0.246 & 0.739 & 0.015 & 0.015 & 0.093 & 0.015 & 0.76 & 0.24 & 1.31 & 0.21 \\
\hline GY & 3 & 14 & 77 & 0.032 & 0.149 & 0.819 & 0.106 & 0.894 & 4.416 & 4.417 & 0.81 & 0.19 & 1.23 & 0.17 \\
\hline WY & 4 & 21 & 74 & 0.040 & 0.212 & 0.748 & 0.147 & 0.856 & 2.351 & 2.351 & 0.75 & 0.25 & 1.33 & 0.22 \\
\hline PY & 2 & 14 & 52 & 0.029 & 0.206 & 0.765 & 0.132 & 0.868 & 0.709 & 0.709 & 0.77 & 0.23 & 1.29 & 0.20 \\
\hline XJ & 4 & 9 & 37 & 0.080 & 0.180 & 0.740 & 0.17 & 0.83 & 6.558 & 6.558 & 0.72 & 0.28 & 1.39 & 0.24 \\
\hline
\end{tabular}

\section{Effect of the IGF-II gene on growth traits}

After the genotypes were identified, the relationships between SNPs and yak growth and carcass traits were analyzed. Table 2 shows the comparison of least square means and respective standard errors of carcass and meat quality traits among different genotypes of the IGF-II polymorphisms. Correlation analysis indicated that in the newborn to 12-month-old WY population, individuals with genotypes $\mathrm{AA}$ and $\mathrm{AB}$ showed significantly stronger effects on LW (weight at 12, 13-24, and 25-36 months of age), ADG $(\mathrm{P}<0.01)$, and carcass weight $(\mathrm{P}<0.05)$ compared to genotype $\mathrm{BB}$ individuals. Animals with genotype $\mathrm{AB}$ had a higher mean REA. However, no significant associations were found with LEA among the newborn to 12- and 13-24-month-old populations. In contrast, in the 25-36-month-old yak populations, individuals with genotype BB had lower mean values for LEA compared with genotype AA and $\mathrm{AB}$ individuals $(\mathrm{P}<0.05)$ (Table 2$)$. For all traits analyzed, homozygotes tended to have higher mean values than heterozygotes.

\begin{tabular}{|c|c|c|c|c|c|c|}
\hline Age (months) & Genotypes & Live-weight (kg) & Average daily gain (g) & Carcass weight $(\mathrm{kg})$ & Loin-eye area $\left(\mathrm{cm}^{2}\right)$ & $\begin{array}{l}\text { Viscera fat } \% \\
\text { of live-weight }\end{array}$ \\
\hline \multirow{4}{*}{ Newborn to 12} & AA & $67.2 \pm 11.3^{\mathrm{B}}$ & $157.8^{\mathrm{b}}$ & $34.3^{\mathrm{b}}$ & 29.2 & 0.9 \\
\hline & $\mathrm{AB}$ & $69.5 \pm 13.6^{\mathrm{B}}$ & $160.5^{\mathrm{b}}$ & $35.4^{\mathrm{b}}$ & 30.4 & 1.1 \\
\hline & $\mathrm{BB}$ & $83.9 \pm 10.8^{\mathrm{A}}$ & $192.2^{\mathrm{a}}$ & $42.8^{\mathrm{a}}$ & 28.7 & 1.1 \\
\hline & AA & $120.1 \pm 11.9^{\mathrm{B}}$ & $152.3^{b}$ & $61.3^{\mathrm{b}}$ & 31.2 & 1.3 \\
\hline \multirow[t]{3}{*}{13 to 24} & $\mathrm{AB}$ & $126.0 \pm 7.1^{\mathrm{B}}$ & $154.8^{\mathrm{b}}$ & $64.3^{\mathrm{b}}$ & 30.6 & 1.2 \\
\hline & BB & $149.3 \pm 10.5^{\mathrm{B}}$ & $167.3^{\mathrm{a}}$ & $76.1^{\mathrm{a}}$ & 29.8 & 1.4 \\
\hline & AA & $154.8 \pm 28.5^{\mathrm{b}}$ & $73.1^{\mathrm{b}}$ & 78.9 & $35.4^{\mathrm{b}}$ & $2.2^{\mathrm{b}}$ \\
\hline \multirow[t]{2}{*}{25 to 36} & $\mathrm{AB}$ & $152.1 \pm 5.4^{b}$ & $71.5^{\mathrm{b}}$ & 77.6 & $31.6^{\mathrm{a}}$ & $1.6^{\mathrm{a}}$ \\
\hline & $\mathrm{BB}$ & $169.2 \pm 4.8^{\mathrm{a}}$ & $84.8^{\mathrm{a}}$ & 86.2 & $30.3^{\mathrm{a}}$ & $1.2^{\mathrm{a}}$ \\
\hline
\end{tabular}

Values with different superscript letters within the same line differ significantly at $\mathrm{P}<0.01(\mathrm{~A}, \mathrm{~B})$ and $\mathrm{P}<0.05(\mathrm{a}, \mathrm{b})$.

\section{DISCUSSION}

The present study is the first report of IGF-II gene polymorphisms in domesticated yak breeds. In this study, 2 SNPs were detected among 5 yak populations at intron 8 of the coding region of the IGF-II gene. The mutations were first detected and classified by DNA se- 
quencing and SSCP analysis. The results of the present study revealed that the $\mathrm{G}_{330} \mathrm{C}$ and $\mathrm{A}_{358} \mathrm{G}$ transitions in the IGF-II gene might affect growth and meat production traits in yaks. For most traits, the AA and BB genotypes appeared to be favorable, which is consistent with the activity of the IGF-II protein as a growth factor (Heude et al., 2007). However, the observed effects were relatively small, thus suggesting that the mutation is not the primary or causative agent for variation in the traits evaluated (Zwierzchowski et al., 2010). Compared with previous cattle research (Goodall and Schmutz, 2003; Zwierzchowski et al., 2010), the IGF-II gene appears to be highly conserved in yaks, and results indicated a very low mutation rate.

It was previously reported that the g.292C $>$ T transition in the IGF-II gene (RFLP$B s r \mathrm{I}$ ) influenced meat production traits in Polish Holstein-Friesian bulls (Zwierzchowski et al., 2010). In a Canadian beef cattle herd, animals with the CT genotype had a significantly lower mean REA relative to those with the CC genotype, but a significantly higher REA than those with the TT genotype (Goodall and Schmutz, 2007). In a steer population, TT genotype animals had a significantly lower mean REA than those with CC and CT genotypes. Furthermore, $\mathrm{CC}$ genotype bulls had a significantly higher mean carcass fat content than those with CT and TT genotypes. Sherman et al. (2008) found that the g.292C $>$ T polymorphism significantly affected several traits related to meat production in a synthetic line of beef cattle. In steers, the allele substitution effect on final body weight was $6.67 \mathrm{~kg}$, in which TT animals were $17.66 \mathrm{~kg}$ heavier than those with the CC genotype, and were $5.71 \mathrm{~kg}$ heavier than CT animals. Animals with the TT genotype also had a higher ADG and a lower feed conversion ratio. In Sherman et al.'s (2008) study, TT homozygous animals had larger REAs, which was not consistent with results of the Goodall and Schmutz (2007) study. The association of a C/T polymorphism in exon 2 of the bovine IGF-II gene with meat production traits in Polish Holstein-Friesian cattle revealed no effect of the IGF-II genotype on live weight; however, the homozygous CC genotype appeared to be favorable for some carcass traits (Zwierzchowski et al., 2010).

In the present study, a clear trend emerged showing intermediate polymorphism at the locus, and the $\chi^{2}$ test indicated that the locus was in Hardy-Weinberg disequilibrium $(\mathrm{P}<0.05)$, which suggests high genetic variation within the population. To investigate the possible functional role of the novel mutation characterized in the yak IGF-II gene, we performed an association analysis over different developmental periods (newborn to 12 months old, 13-24 months old, and 25-36 months old) of a WY population for which diverse carcass and fat deposition traits were recorded (Table 2). Due to slaughter costs and operational convenience (Ding et al., 2012), the 110 Tianzhu WYs were selected for analysis of the carcass and fat deposition traits. Correlation analysis indicated that in the newborn to 12-month-old WY population, genotypes $\mathrm{AA}$ and $\mathrm{AB}$ were more associated with $\mathrm{LW}, \mathrm{ADG}(\mathrm{P}<0.01)$, and carcass weight $(\mathrm{P}<0.05)$ relative to individuals of genotype BB. Animals with genotype AB had a higher mean REA. However, no associations were observed with LEA among the newborn to 12- and 13-24-month-old populations. In contrast, in the 25-36-month-old yak populations, individuals with genotype $\mathrm{BB}$ had lower mean LEA than those with genotype $\mathrm{AA}$ and $\mathrm{AB}(\mathrm{P}<0.05)$. This result confirms previous reports showing the influence of a G/A mutation in intron 3 of the paternally expressed IGF-II gene on muscle growth (Jeon et al., 1999; Nezer et al., 1999; Van Laere et al., 2003). Furthermore, a paternally expressed QTL for muscle growth and back fat thickness was identified near the distal end of the chromosome 2 pig IGF-II locus (Jungerius et al. 2004).

The results of the present study indicate that mutations of the intron 8 region of the yak IGF-II gene have potential to be used as genetic markers linking to QTLs with effects on 
carcass traits, fat deposition, and meat quality. Association analyses with more animals are nonetheless required before this gene can be considered as a genetic marker.

\section{ACKNOWLEDGMENTS}

Research supported or partially supported by grants from the National Natural Science Funds of China (Grant \#31101702), the National Science \& Technology Pillar Program during the "Twelfth Five-year" Plan Period (\#2012BAD13B05), and the Special Fund for Agro-Scientific Research in the Public Interest (Contract \#201003061).

\section{REFERENCES}

Adams GR (2002). Invited Review: Autocrine/paracrine IGF-I and skeletal muscle adaptation. J. Appl. Physiol. 93: 1159-1167.

Bamman MM, Shipp JR, Jiang J, Gower BA, et al. (2001). Mechanical load increases muscle IGF-I and androgen receptor mRNA concentrations in humans. Am. J. Physiol. Endocrinol. Metab. 280: E383-E390.

Casas-Carrillo E, Prill-Adams A, Price SG, Clutter AC, et al. (1997). Relationship of growth hormone and insulin-like growth factor-1 genotypes with growth and carcass traits in swine. Anim. Genet. 28: 88-93.

Curchoe C, Zhang S, Bin Y, Zhang X, et al. (2005). Promoter-specific expression of the imprinted IGF2 gene in cattle (Bos taurus). Biol. Reprod. 73: 1275-1281.

Dindot SV, Farin PW, Farin CE, Romano J, et al. (2004). Epigenetic and genomic imprinting analysis in nuclear transfer derived Bos gaurus/Bos taurus hybrid fetuses. Biol. Reprod. 71: 470-478.

Ding XZ, Liang CN, Guo X, Xing CF, et al. (2012). A novel single nucleotide polymorphism in exon 7 of LPL gene and its association with carcass traits and visceral fat deposition in yak (Bos grunniens) steers. Mol. Biol. Rep. 39: 669-673.

Flisikowski K, Adamowicz T, Strable T and Jankowski T (2006). An InDel polymorphism in extron IGF2 associated with the breeding value of Polsih Holstein-Friesian Bulls. Biochem. Genet. 45: 139-142.

Florini JR, Ewton DZ and Coolican SA (1996). Growth hormone and the insulin-like growth factor system in myogenesis. Endocr. Rev. 17: 481-517.

Goodall JJ and Schmutz SM (2003). Linkage mapping of IGF2 on cattle chromosome 29. Anim. Genet. 34: 313.

Goodall JJ and Schmutz SM (2007). IGF2 gene characterization and association with rib eye area in beef cattle. Anim. Genet. 38: 154-161.

Haugk KL, Roeder RA, Garber MJ and Schelling GT (1995). Regulation of muscle cell proliferation by extracts from crushed muscle. J. Anim. Sci. 73: 1972-1981.

Heude B, Ong KK, Luben R, Wareham NJ, et al. (2007). Study of association between common variation in the insulinlike growth factor 2 gene and indices of obesity and body size in middle-aged men and women. J. Clin. Endocrinol. Metab. 92: 2734-2738.

Jeon JT, Carlborg O, Tornsten A, Giuffra E, et al. (1999). A paternally expressed QTL affecting skeletal and cardiac muscle mass in pigs maps to the IGF2 locus. Nat. Genet. 21: 157-158.

Joseph S and David WR (2002). Molecular Cloning: a Laboratory Manual. 3rd edn. Science Press, Beijing.

Jungerius BJ, van Laere AS, Te Pas MF, van Oost BA, et al. (2004). The IGF2-intron3-G3072A substitution explains a major imprinted QTL effect on backfat thickness in a Meishan x European white pig intercross. Genet. Res. 84: 95-101.

Levinovitz A, Jennische E, Oldfors A, Edwall D, et al. (1992). Activation of insulin-like growth factor II expression during skeletal muscle regeneration in the rat: correlation with myotube formation. Mol. Endocrinol. 6: 1227-1234.

Marsh DR, Criswell DS, Hamilton MT and Booth FW (1997). Association of insulin-like growth factor mRNA expressions with muscle regeneration in young, adult, and old rats. Am. J. Physiol. 273: R353-R358.

Nezer C, Moreau L, Brouwers B, Coppieters W, et al. (1999). An imprinted QTL with major effect on muscle mass and fat deposition maps to the IGF2 locus in pigs. Nat. Genet. 21: 155-156.

O’Dell SD and Day IN (1998). Insulin-like growth factor II (IGF-II). Int. J. Biochem. Cell Biol. 30: 767-771.

Salmon WD Jr and Daughaday WH (1957). A hormonally controlled serum factor which stimulates sulfate incorporation by cartilage in vitro. J. Lab. Clin. Med. 49: 825-836.

Sherman EL, Nkrumah JD, Murdoch BM, Li C, et al. (2008). Polymorphisms and haplotypes in the bovine neuropeptide $\mathrm{Y}$, growth hormone receptor, ghrelin, insulin-like growth factor 2, and uncoupling proteins 2 and 3 genes and their 
associations with measures of growth, performance, feed efficiency, and carcass merit in beef cattle. J. Anim. Sci. 86: 1-16.

Van Laere AS, Nguyen M, Braunschweig M, Nezer C, et al. (2003). A regulatory mutation in IGF2 causes a major QTL effect on muscle growth in the pig. Nature 425: 832-836.

Zhao Q, Davis ME and Hines HC (2002). Associations of an AciI Polymorphism in the IGF-II Gene with Growth Traits in Beef Cattle. In: Proceeding of the 7th World Congress on Genetics Applied to Livestock Production, Montpellier.

Zwierzchowski L, Siadkowska E, Oprządek J, Flisikowski K, et al. (2010). An association of C/T polymorphism in exon 2 of the bovine insulin-like growth factor 2 gene with meat production traits in Polish Holstein-Friesian cattle. Czech J. Anim. Sci. 55: 227-233. 